\title{
Housing Conditions in the FCT, Abuja-Nigeria: A Case Study of Gwagwalada Satellite Town
}

\author{
Ekpetere O. Kenneth $^{1^{*}} \quad$ Ekeh O. Faith ${ }^{2 *} \quad$ Eziechi M. Nkechi ${ }^{3}$ \\ 1.Department of Geography and Environmental Management, University of Abuja, PMB117, Abuja, Nigeria \\ 2.Department of Botany, Faculty of Biological Sciences, Nnamdi Azikiwe University, Nigeria \\ 3.Department of Public Health, Federal University of Technology Owerri, Imo State Nigeria
}

\section{ABSTRACT}

The research investigated the housing conditions and problems in the Federal Capital city of Abuja-Nigeria: using Gwagwalada satellite town as a case study. The research also examine; the nature of housing pattern in the study area, causes of poor housing conditions in the study area and the effects of poor housing conditions in the study area. Data was sourced from both primary and secondary sources. At the end of the research, it was revealed that, the causes of poor housing conditions in the study area were; Population explosion, lack of proper waste management and uneven spacing of buildings which creates un-conducive environment among others. The study also showed that, there exist; dilapidating buildings especially in the unplanned sections; poor road network in some areas; poor waste disposal and management; and lack of good water supply in some areas. Recommendations were proffered which include; strict implementation of laws governing building, its standard and requirements and provision of necessary neighborhood facilities within the reach of the individual housing units in the study area, maintaining already existing structures and discouraging house owners from building sub-standard houses by ensuring they provide their building plans before commencing such projects.

Keywords: Housing conditions, housing patterns, public health, dilapidated buildings, domestic waste, waste management, substandard houses, building materials, population explosion, building policies, building laws, housing Units, basic amenities, building infrastructures, Gwagwalada satellite town.
\end{abstract}

DOI: $10.7176 / \mathrm{JEES} / 9-4-13$

Publication date: April $30^{\text {th }} 2019$

\section{INTRODUCTION}

Housing is very essential to every nation's economy. It reflects the social status the psychological welfare of the citizens including their being and also their level of development among other things (Yusuf, 2012). Housing is often regarded as one of the basic human needs it ranks second after food and there after clothing. It is a prereinitiate for the survival of man (Onibokun, 2002). Housing as a unit of the environment has profound influence on the health, efficiency, social behavior, satisfaction and general welfare of the community. It reflects the cultural, social and economic values of a society as it is the best physical and historical evidence of the civilization of a country. Adedeji (2012) argued that housing issues affect the life of individuals as well as that of a nation; hence both nature and society ascribed great importance to the role it plays to bring about human comfort (Adedeji, 2012).

The Gwagwalada Area Council just like most other area councils in Abuja consists of the planned areas and the unplanned areas. The nature and structure of housing pattern in the planned areas differ from those of the unplanned area (Jackson, 2010). This also goes down to reveal the standards of living of people living in both places (Jackson, 2010).

Poor housing condition which can be as a result of influx of people leading to overcrowding and pressure on the existing infrastructure and amenities can result to detrimental consequences on the people themselves outbreak of diseases, lack of comfort and deterioration of infrastructures among other consequences increases leading to poor living conditions (Lucas, 2011).

Lucas (2011) also stated that our cities have continued to experience the influx of people because of the concentrations of economic and social activities and infrastructures in the cities as well as the pressure and expectation of gainful employment by people from rural areas. The rate of urbanization and the resultant effects such as housing shortage, overcrowding congestion, high occupancy rate and the over stretching of existing facilities in such areas has forced both high and low income earners to settle at the periphery of cities where they can get access to land for building construction.

The deplorable condition of the housing environment in the inner core of the cities has also motivated people to move out to the suburbs. This they do hoping to acquire some form of decent housing of their own. High cost of accommodation has also propelled some people to move to the suburb and build their own houses even though the houses do not meet up to standard. Most of these low standards kind of houses are built in the rural areas where use or no attention is given to strict adherence to building regulation and housing policies (Yusuf, 2012).

The aim of this research is to assess the condition of housing in the Federal Capital city of Abuja-Nigeria: 
using Gwagwalada satellite town as a case study. In order to achieve the aim stated above the following objectives were pursued:

- $\quad$ To examine the nature of housing pattern in the study area.

- $\quad$ To examine the housing conditions and standards of building in the study area.

- $\quad$ To determine the causes of poor housing conditions in the study area.

- To show the effects of poor housing conditions in the study area.

\section{THE STUDY AREA}

The study area is Gwagwalada town. Gwagwalada town is one of the largest satellite towns and the third largest urban centre in the Federal Capital Territory (NPC, 1991). It is one of the most densely populated areas in the federal capital territory (FCT) and the headquarters of one of the oldest councils in the Federal Capital Territory, Abuja (Ejaro, 2013). Nigeria new Federal Capital Territory was established in 1991, all federal establishments were meant to relocate their corporate headquarters to Abuja. The city witnessed a tremendous influx of civil servants and the organized private sector bringing about an explosion of population into and around the federal capital city (FCC). As a result Gwagwalada also witnessed remarkable expansion and increased land conversion rate leading to temperature increase over time. The gradual loss of vegetal cover for construction and subsequent buildings and urbanization generally led to temperature increase in Gwagwalada town with time (Ejaro, 2013). Gwagwalada town is located about 55 kilometers away from federal capital city (FCC) within the Federal Capital Territory. It lies between latitude $08^{0} 55^{\prime} \mathrm{N}$ and $09^{\circ} 00^{\prime} \mathrm{N}$ and longitude $07^{\circ} 00^{\prime} \mathrm{E}$ and $07^{\circ} 05 \mathrm{E}$ (Balogun, 2001). Gwagwalada township region has a total land mass of about 6,500 hectares.

Gwagwalada town consists of the older traditional and new planned sections. The old is the pre-1976 section, while the latter results from the development of the Federal Capita Development Authority in accordance with its planned role in the spatial development of the Federal Capital Territory (FCT). Its two parts internal structure is quite similar to the pre-colonial urban centres in western and northern parts of Nigeria (Balogun, 2001). The urban or planned areas are places in Gwagwalada, where the development of the town is intended to spread out from hence acting as growth pole of Gwagwalada town such places are phase1,2,and 3, (FCDA, 2000).

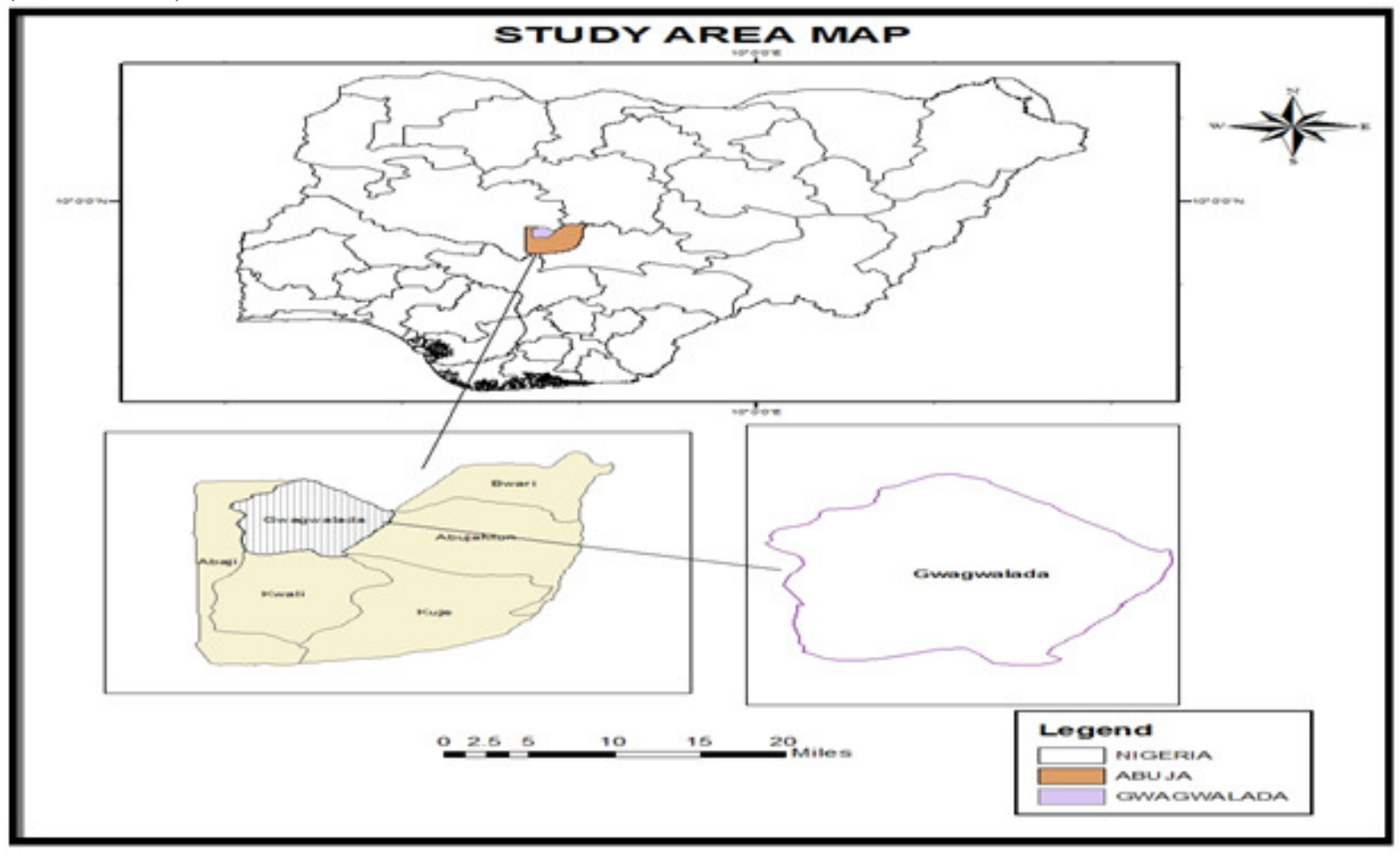

Fig. 1: Map of the Study Area

Source: Department of Land use Administration, Gwagwalada Area Council (2018) 


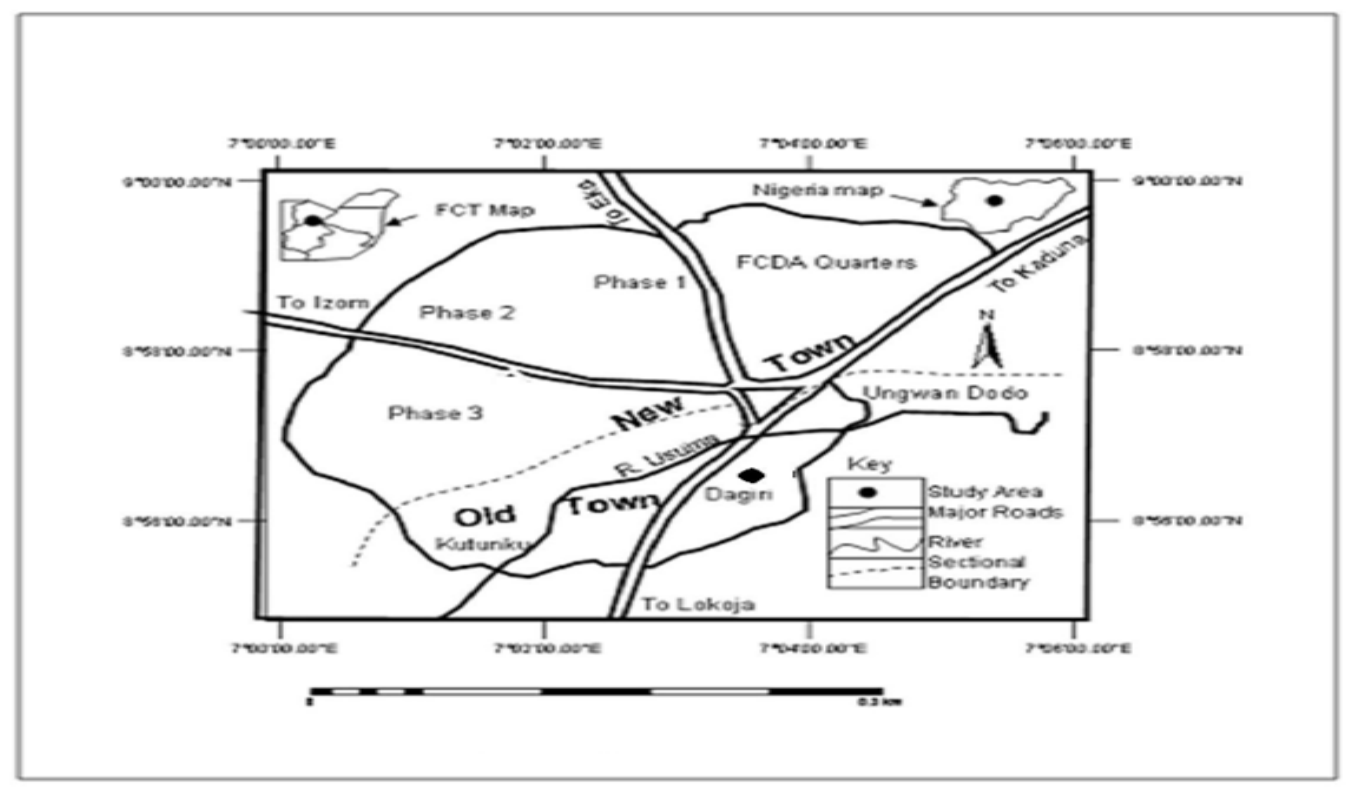

Fig.2: Map of Gwagwalada Town

Source: Department of Land use Administration, Gwagwalada Area Council (2018)

\section{LITERATURE REVIEW}

\subsection{Concept of Housing}

Onibokun (2002) explained that housing is a unit of the environment which has a profound influence on the health, efficiency, social behavior, ratification and general welfare of the community. Housing is not about shelter, it is the totality of the immediate physical environment, which encompasses all the social and cultural facets together with infrastructure and utilities built on the foundations of the economics of finding the affordability (Yusuf, 2012). The human passion to own a home of their own is capable of driving the citizen of the country to work harder, sailplaner and create a more productive and economically visible society (Yusuf, 2012).

Housing is one of the three basic needs of mankind and it is the most important for the physical survival of man after the provision of food. It is also one of the best indicators of a person standard of living and of his place in the society. In spite of the fact that housing is part of the urbanization process and a measure of a country's level of development and standard of living, housing continues to be regarded as an economically nonproductive investment, as wholly resources absorbing rather than resource producing. The provision of shelter has been viewed by policy makers as something to be tolerated rather than desired. This attitude by policy makers has resulted in housing being given low priority in Nigerian development planning (Adeniyi, 2014). However, Onibokun (2012) wrote that the concept of housing is so broad that there is no agreement in the existing literature as to the exact meaning or definition of housing. This is one rightly to the multi-dimensional nature of housing itself. Housing entails more than shelter for human habitation as it encompasses the physical structure in addition to the immediate surrounding or environment. In other words, housing encompasses the immediate environment, sanitation, drainage, recreational facilities, and other economic and social activities that make life worth while. In the urban centers it "represent the largest use of urban", while it promotes the setting for the information social relationship both in the urban as well as rural area (Amole, 2012).

Housing is a spatially even resource with varying costs and qualities is unevenly distributed over space. The difference in cost and quality coined be attributed to housing production which encompasses the construction of new houses; the up-grading of the existing housing stock (i.e. extent of maintenance renovation and rehabilitation) and the distribution of new as well as the up-grading housings (Agbola, 2015). One may perhaps be tempted to ask why emphasis is being placed on housing. Firstly, of all man's basic needs housing arguably, constitutes and indeed poses the great challenge. Secondly, a vigorous and buoyant housing sector is an indication of a strong programmes of national investment and one indeed the foundation of and the first step of future economic growth and social development. The gross housing delivery is therefore a major factor in the nation's domestic product and indeed this reflects the state of health of the nation. To further apprehend the contribution of housing to national development, the need for and motives behind housing needs to be indentified. The magnitude of the housing problems varies from country to country and city to city, but without deliberates under estimation of the frequently inadequate housing. 


\subsection{Housing Quality}

Housing quality may reflect the values of the social group to which the residents in a specific housing unit belong. This may be evident in places like America where choice of housing is made based on educational opportunities and value offered to their children (Amole, 2012). A report on housing in Africa produced by the united nation in 1978 describes clearly that "the situation is getting worse due to the increase in population growth and urbanization. The fifth session of the united nations committee on housing, building and planning, held in Geneva in October 1967 agreed the little general progress had been achieved recently in this field, and that the cause of housing is being downgraded (Amole, 2012).

Adeniyi (2014) in his report that features in the Nigerian journal of economic and social studies argued that the planners of the second National development plan recognized that "Housing difference in both quantitative and qualitative terms is a universal problem in the country and this is readily recognized in the urban centre and is manifested house and soaring house rents. It is however intense to emphasize the importance of housing in national development; to examine the amount of efforts in the provision of housing in Nigeria and to suggest policies and programmes carried at solving the housing problem. Yunusa, (2013) also argued in the same vein that housing problems manifest themselves in both a quantitative manner. Therefore from the foregoing, it has been made evidently clear that housing conditions must be viewed in a multi-dimensional perspectives i.e. not just the housing quality alone but also the quality of housing. Housing space and quality both improve systematically as economic development process.

In general higher incomes associated with economic development permit, greater spending on housing, which is in turn reflected in better housing -more spacious, more durable, with more recurred tenure and with the better facilities. Evaluation of differences among countries in housing out-comes, however, suggests that even for countries at the same level of economic development, housing outcomes very considerably. These variations tend to be heavily influenced by housing policies. For example, urban household in Hong-Kong and others, Greece have similar incomes but quite different housing conditions and cost. In 1990, 26 and 76 square meters of flour area and were valued at US\&112,000 and US\$ 54,000 respectively (Adeniyi, 2014). Onibokun (2012) explained that the major determinants of urban housing condition $\mathrm{s}$ in Nigeria include:

- $\quad$ The age of dwellings.

- The types of building and the material used in their construction.

- The variety grid adequacy of facilities provided on dwellings.

- The mode of handling various aspects of housing construction such as site preparation, building of foundation, construction of walls and roofing.

To these may be added the physical and climatic factions which affect the durability of dwellings, as well as the social and cultural factors which influence the ways of people perceive the quality o their own housing and of the neighborhood in which such housing is located. The spectacular differences in the level of maintenance between dwellings in the core area of the cities and the newer suburbs can partly be explained in terms of differences in the age and materials of buildings used and towards maintenance (Onibokun, 2012).

\subsection{Housing Pattern and Structures}

No two settlements have exactly the same building pattern and structure especially when the locations are far apart. Through when the same town planning policy is required, the structures are expected to have the same standard (Major, 2013).

\section{- Loose-Knit Settlement Pattern}

Loose-knit or fragmented settlement pattern consists of scattered dwellings which are irregularly spaced. However, it is not enough to call each of the fragments isolated dwellings. These forms of settlement suggest that there may not be so much interrelation between the dwellings with exception of sharing common public utilities like borehole (Major, 2013).

- Clustered Settlement Pattern

A cluster or nucleated settlements has a form which shows dwellings close together. In most cases, clustered settlement pattern are formed in response to trade links or response to defense. The clustered settlement could be of various shapes such as Y, T or Cruciform, while some may be star shape (Major, 2013).

- Linear Settlement Pattern

Linear settlements have their dwellings aligned along the roads, rivers, canals and along valley ridges. This type of formation is usually found where strip farming is practiced. The linear settlement pattern could be formed in response to some tourist attraction; others may have been conditioned topography or drainage pattern (Major, 2013).

\section{- Open Space Settlement Pattern}

Open space settlement pattern is mainly a rural settlement pattern, where dwellings are around a central open space such as market centre or open green land. The dwellings in this formation usually face inward so that 
houses on the opposite side look towards each other, most of the village in Nigeria is of these form and they are probably formed in response to defense against intruders. During the time of unrest, the inhabitants can use the open space to their advantage (Major, 2013).

\section{- Double-Linked Settlement Pattern}

The double-linked or double village settlement pattern may be in form of two settlement nearly located together. In most cases, the two settlements maybe called the same name but distinguished by putting some word which differentiate the two like adding the word "-north", "-south", "old", "new", "east", "west", "up", "down", etc, as the case may be. This formation show that the two places have common origin and that the settlements are probably started by the same family (Major, 2013).

\subsection{Poor Housing Conditions and their causes}

Poor housing condition can be as a result of the following;

- Lack of Sufficient Building Materials

Insufficiency in terms of building materials can lead to a compromise. Where the building material are not enough or cost become too high that the middle class and the how class citizens cannot afford the standard building materials, they will sought for alternatives. Most of the unsupervised buildings in most home and cities today lack modern facilities, the result of this can be seen through constant building collapse in most towns as well as rapid dilapidation of buildings (Adeniyi, 2014). In some unplanned areas, the people uses mainly mud for building instead of bricks, conjugated roofing sheets instead of modern roofing sheets as well as other unstandardized materials, (Major, 2013).

- Poverty

Poverty is one of the major influences on poor building conditions. A poor man does not have the financial resources to build and maintain a standard house. Building a house is not enough but the maintenance can be very costly and tasking. According to Egunjobi (2012), a house is one of the indices for measuring standard of living, as people cannot give out what they donor has. A rich man can afford a standard house with all the facilities in place as oppose a poor man who can hardly fend for himself (Egunjobi, 2012).

- Bad/Poor Construction

It has become rampant and a norm in most part of the country when cases of collapsed structures, and fire outbreaks on malls and buildings are mentioned. Bad construction without rudimental checks can cause divesting effects resulting to loss of lives and properties. In most part of the country today, building collapse has become rampant and in most cases nothing is done to neither abate nor address this problem for future reoccurrence (Major, 2013).

- Poor Drainage System

The unplanned or rural areas are characterized by poor drainage system, irregular dumping sites, and offensive odor emanating from the poor drainage channels. Most of the places are not well planned and provisions are not made for underground water, hence heavy down pour results to surface water and debris along high ways, (Egunjobi, 2012).

\section{- Population Explosion (Overcrowding)}

overcrowding has been known over the years to be a contributing causes to poor housing condition influx of people into a place or region due to either the push factors which propels them from their places of origin or sources (such as war, unfavorable climate, famine, unfavorable government policies, and so on) or the pull factors which attracts them to the destination region (such as social and basic amenities), has led to pressure on available resources, pressure on the environment as well as acute environmental degradation (Egunjobi, 2012). People have been known to given up their apartment to accommodate the new comers in exchange for money in form of rent. There has been pressure on available resources, exploitation leading to degradation of the environment (Major, 2013).

- Political Instability

The changing of government over time in various regions has caused lapses in the housing sector. Government that gives utmost priority to housing achieves the desired goal of providing standard houses to its citizenry. By changing government over time means that most building projects are abandoned when the new government have no serious interest in the building project but face other sectors of the economy (Adeniyi, 2014).

\subsection{Effects of Poor Housing Condition}

It is universally accepted that housing is the second most important need of man after, food (Aluko, 2016). Housing transcends shelter and thus comprises of the facilities and other social services within the environment which links man with his remote and immediate neighborhood. It encompasses the totality of the environment and infrastructure which provide human comfort, enhance people health and productivity as well as enable then to sustain then psycho-social or psycho-pathological balance in the environment where they find housing 
transcends its physical dominion. The quality of life in the urban centre depends to a large extent on the availability of social service including health, education and urban infrastructure (Egunjobi, 2012).

A community that lacks safe, decent and livable housing is actually paying a variety of hidden costs which may hamper with its economic productivity. The effects of poor housing conditions can be itemized as follows:

- $\quad$ Collapsing of structures not properly erected over time

- Spread of diseases due to overcrowding

- $\quad$ dilapidation of building structures

- loss of comfort

- $\quad$ Growth of dumping sites

- $\quad$ emanating of offensive odor due to poor sanitation

- $\quad$ overcrowding and over population

- $\quad$ flash flooding during and after rainfall

- $\quad$ Blockage of drainage channels, (Lucas, 2011).

\subsection{Indices Used in Measuring Housing Conditions}

There are many variables that can be used to determine the condition of housing in any location at a given time. These indices are sometimes used inter changeable with criteria. Nwotana, (2013) posits that he problem of housing in Nigeria today cannot be strictly defined in terms of housing cost, building materials, man power availability and land tenure system. He maintained that the general housing condition can be viewed from the following perceptive:

- Types of residential building.

- $\quad$ Spatial usage pattern.

(i) Type of residential building: This includes the "rooming" and flat types, the mean plot size per person, the mean number of the house holds per residential building.

(ii) Spatial usage pattern: The way people use and organize their dwelling places vary not only according to cultural factors and environmental realities. In son cities space is used in a most unselected way. Resident use the starts, or adjoining public space as a living space home.

Onibokun (2002) used the following indices a measure of housing quality and measure of assessment

- the physical condition of the building

- $\quad$ environmental sanitation

- accessibility and availability of facilities

- $\quad$ building materials

- $\quad$ occupancy ratio

- $\quad$ the qualitative appraisal method

- the standard scaling technique

- $\quad$ the single value method

- the perception approach

\subsection{Socio-Economic Aspect of Housing}

The human passion to own a home of their own is capable of driving the citizens of a country to work harder, save longer and create a more productively and economically enable society (Yusuf, 2012). It is generally agreed that people who own their homes do not destroy buildings, because they have messed interest in the society and would protect the stability of the nation (Yusuf, 2012). Social factors often motivate the setting up of natural housing programs owning to the fact that the over crowded, in sanitary conditions of slum areas may lead to increase in diseases, crime and general social and perhaps political unrest (Yusuf, 2012). Economic gains fro the provision of housing are often links on investment in housing as "non-productive" and government usually put forward economic reasons as an excuse for taking little or no action. This high result from an error of judgment in housing is not only "productive" but forms an integral pat of the economic development process, (Adeniyi, 2014). It is still far from easy to demonstrate conclusively the economic gains, which can result from the adequate housing of a nation population, the example of Brazil where a National Housing Bank was created in 1964 and which more than any other factor contributed to the restoration of the economy as well as lay the basis for guided urban development, is a living evidence of the important role which housing could play in economic development (Yusuf, 2012).

The role of housing in capital formation in Nigeria and in generating general economic growth through many raised subsidiary or ancillary activities in the economy impinging upon it cannot be over emphasized. This role in Nigeria has been noted as early 1960 when it was claimed that buildings constitute by far the most important single sector of capital formation, accounting for an average of $40 \%$ of gross fired investment over the period of 1951-1958 and directly employs about a quarters of the registered labor force (Adeniyi, 2014). In 
addition to the desire to own a house is one of the strongest incentives for saving and domestic capital formation so that this alone makes housing a powerful tool of economic development in the country. Housing as a subject for research continues to be neglected by Nigerian economist (Yusuf, 2012).

\section{MATERIALS AND METHODS}

\subsection{Sample Size}

Krejcie model for sample size determining was adopted and postulated below for the study;

$$
\mathrm{S}=\quad \mathrm{x}^{2} \mathrm{NP}(1-\mathrm{P})
$$

$$
d^{2}(\mathrm{~N}-1)+\mathrm{x}^{2} \mathrm{P}(1-\mathrm{P})
$$

where;

$\mathrm{S}=$ required sample size, $\mathrm{X}^{2}=$ the table of value for 1 degree of freedom at the desired confidence level.

$\mathrm{N}=$ the population size, $\mathrm{P}=$ population proportion (assumed to be 0.50 ) since this would provide the maximum sample size, $d=$ degree of accuracy expressed as a proportion (0.05), Hence, at 66,993 H.H.M, the sample size is 382.

\subsection{Purposive Sample}

The questionnaires designed were administrated to household heads. In cases were selected household were not available or was discovered to be a filling station or school, such households or sample were skipped and the next household was been considered.

4.3 Sample Frame

Table 1: Summary of sample frame, size and questionnaire distribution

\begin{tabular}{|l|l|l|l|l|l|}
\hline S/N & Location & $\begin{array}{c}\text { 2016 population } \\
\text { (NPC) }\end{array}$ & $\begin{array}{c}\text { Population } \\
\text { projection (2016) }\end{array}$ & $\begin{array}{c}\text { Household Mean } \\
\text { (HHM) }\end{array}$ & $\begin{array}{c}\text { No of } \\
\text { Questionnaire/ } \\
\text { Sample Size }\end{array}$ \\
\hline 1 & Zuba & 26,965 & 68339 & 11389 & 65 \\
\hline 2 & Ibwa & 12689 & 32158 & 5359 & 31 \\
\hline 3 & Dobi & 9517 & 24119 & 4019 & 23 \\
\hline 4 & Kutunku & 25378 & 64317 & 10719 & 61 \\
\hline 5 & Tunga maje & 20620 & 52259 & 8709 & 50 \\
\hline 6 & Gwako & 15068 & 38188 & 6364 & 36 \\
\hline 7 & Paikon-kore & 15861 & 40197 & 6699 & 38 \\
\hline 8 & Ikwa & 11103 & 28139 & 4689 & 27 \\
\hline 9 & Quarters & 7930 & 20097 & 3349 & 19 \\
\hline 10 & Central & 13487 & 34187 & 5697 & 32 \\
\hline & Total & $\mathbf{1 5 8 , 6 1 8}$ & $\mathbf{4 0 2 , 0 0 0}$ & $\mathbf{6 6 9 9 3}$ & $\mathbf{3 8 2}$ \\
\hline
\end{tabular}

Source: Author Survey, 2018.

4.4 Data Presentation and Statistical analysis

The research adopts various methods of data presentation and analysis; simple bar graphs, pie charts and tables. The chi-square was employed in testing the hypothesis.

It is expressed mathematically as:

Chi-square $\mathrm{x}^{2}=\sum_{\mathrm{i}=1}^{\mathrm{k}} \frac{(0-\mathrm{E})^{2}}{\mathrm{E}_{\mathrm{i}}}$

Where; $\mathrm{O}_{\mathrm{i}}=$ observed value, $\mathrm{E}_{\mathrm{i}}=$ Expected values

\section{RESULTS AND DISCUSSION}

\subsection{Nature of Housing Pattern and Conditions}

This subsection carefully analyses the nature pattern and conditions of housing in Gwagwalada. These analyses include the pattern of housing arrangement, source of water supply, roofing materials used in Gwagwalada, waste disposal system, road network accessibility, frequency of power supply, household mean as well as the availability of basic amenities in Gwagwalada.

\subsection{Pattern of Housing Arrangement}

This subsection analyses the pattern of housing arrangement in Gwagwalada. 
Table 2: Pattern of housing arrangement in Gwagwalada

\begin{tabular}{|l|l|l|l|}
\hline S/N & Pattern of Arrangement & Frequency & Percentage (\%) \\
\hline 1 & Dispersed/isolated & 149 & 39.0 \\
\hline 2 & Nucleated & 198 & 51.8 \\
\hline 3 & Double linked settlements & 20 & 5.2 \\
\hline 4 & Others & 15 & 4.0 \\
\hline & Total & $\mathbf{3 8 2}$ & $\mathbf{1 0 0}$ \\
\hline
\end{tabular}

\section{Source: Field survey, 2018}

Table 2 shows that $39.0 \%$ of the respondents attest that the pattern of housing arrangement in the study area is dispersed or isolated in arrangement. $51.8 \%$ are of the view that the houses are nucleated. In other words, the buildings are so close to one another especially in areas where the lands are highly fragmented and sold out. $5.2 \%$ of the respondents are of the opinion that the housing pattern are arranged in a table set, in this case, locations tends to be distinguished using north, south, east and west. Example is Old and New Kutunku. 4.0\% of the respondents are not sure of the pattern of housing arrangement in Gwagwalada. From the analysis above, $51.8 \%$ of the respondents averted that the housing pattern in the study area is nucleated. This pattern of housing structure can possibly affects the housing condition of the people due to poor ventilation of air. In a similar assertion, UN habitat (2006), submitted that good quality housing means not just a root over one's head but also sustainable environment through proper and adequate ventilation.

\subsection{Source of Water Supply}

This subsection analyses the source of water supply in Gwagwalada.

Table 3: Source of water supply in Gwagwalada

\begin{tabular}{|l|l|l|l|}
\hline S/N & Source of water supply & Frequency & Percentage (\%) \\
\hline 1 & Tap & 148 & 38.7 \\
\hline 2 & Borehole & 104 & 27.2 \\
\hline 3 & Well & 124 & 29.8 \\
\hline 4 & Stream/River & 10 & 2.6 \\
\hline 5 & Others & 6 & 2.7 \\
\hline & Total & $\mathbf{3 8 2}$ & $\mathbf{1 0 0}$ \\
\hline
\end{tabular}

Source: Field survey, 2018.

Table 3 above shows that $38.7 \%$ above are of the opinion that water supply in Gwagwalada, 27.25 attest to the reliance on borehole water as the main source of water supply, 29.8\% of the respondents attest to the use of well as their main source of water supply. About $2.6 \%$ of the respondents are dependent on stream/river water especially those living closer to river bodies in Gwagwalada. While $1.7 \%$ of the respondent were of the opinion that neither of the sources of water mentioned above are related to them, as they depend on other sources such as regular water supply using water tankers among others.

\subsection{Roofing Materials in Gwagwalada}

This subsection analyses the kinds of roofing materials used in Gwagwalada

Table 4: Roofing Materials used in Gwagwalada

\begin{tabular}{|l|l|l|l|}
\hline S/N & Roofing Materials & Frequency & Percentage (\%) \\
\hline 1 & Corrugated roofing sheet & 154 & 40.3 \\
\hline 2 & Aluminum & 198 & 51.8 \\
\hline 3 & Thatch & 5 & 1.3 \\
\hline 4 & Others & 25 & 6.6 \\
\hline & Total & $\mathbf{3 8 2}$ & $\mathbf{1 0 0}$ \\
\hline
\end{tabular}

Source: Field survey, 2018.

Table 4 above shows that the respondents were of the opinion that $40.3 \%$ of the roofing materials used in Gwagwalada are made of corrugated roofing sheet, $51.8 \%$ of the roofing sheets were made of Aluminum, $1.3 \%$ of the roofing sheets especially in the typical rural settings of villages in Gwagwalada were made of thatch and leaves. $6.6 \%$ of the respondents attest to the use of other roofing materials such as wood, polythene, asbestos among others in Gwagwalada.

\subsection{Waste Disposal Mechanism in Gwagwalada}

This subsection discusses the mechanism of disposing waste in Gwagwalada. 
Table 5: Methods of Waste Disposal in Gwagwalada

\begin{tabular}{|l|l|l|l|}
\hline S/N & Methods of waste disposal & Frequency & Percentage (\%) \\
\hline 1 & Incineration & 33 & 8.6 \\
\hline 2 & Burying & 48 & 12.6 \\
\hline 3 & Dumpsite & 161 & 42.0 \\
\hline 4 & Recycling & 25 & 6.5 \\
\hline 5 & Others & 115 & 30.3 \\
\hline & Total & $\mathbf{3 8 2}$ & $\mathbf{1 0 0}$ \\
\hline
\end{tabular}

Source: Field survey, 2018

Table 5 above shows that the respondents were of the view that $8.6 \%$ of the method of disposing waste in Gwagwalada is done by incineration. $12.6 \%$ of the waste disposal system is done by burying, $42.0 \%$ of the waste generated is disposed through recycling, by making them reusable. $30.3 \%$ of the wastes are disposed through other means such as burning, compost making especially green manure among others. From the analysis, it was observed that $42.0 \%$ the major implication of poor housing condition in the study area is poor and improper waste management. Good quality housing is important if there is adequate sanitation and waste management facilities. Therefore, poor and improper waste management have been observed to be among the major effect of poor housing condition.

\subsection{Accessibility of Road Network}

This subsection analyses the accessibility of road network in Gwagwalada.

Table 6: Road Network Accessibility in Gwagwalada

\begin{tabular}{|l|l|l|l|}
\hline S/N & Road Network Accessibility & Frequency & Percentage (\%) \\
\hline 1 & Very accessible & 150 & 39.3 \\
\hline 2 & Moderately accessible & 212 & 55.5 \\
\hline 3 & Poorly accessible & 20 & 5.2 \\
\hline & Total & $\mathbf{3 8 2}$ & $\mathbf{1 0 0}$ \\
\hline
\end{tabular}

Source: Field survey, 2018

Table 6 shows that $39.3 \%$ of the respondents are of the opinion that their road network is very accessible, $55.5 \%$ are of the opinion that their road network are moderately accessible while $5.2 \%$ of the respondents attest to poor accessible road network in the study area. The analysis shows that road network in Gwagwalada is majorly accessible.

\subsection{Frequency of Power Supply}

This subsection analyses the frequency of power supply in Gwagwalada.

Table 7: Frequency of Power Supply in Gwagwalada

\begin{tabular}{|l|l|l|l|}
\hline S/N & Frequency of power supply & Frequency & Percentage (\%) \\
\hline 1 & Constant & 51 & 13.3 \\
\hline 2 & Rational & 146 & 38.2 \\
\hline 3 & Rarely & 83 & 21.7 \\
\hline 4 & No power supply & 102 & 26.8 \\
\hline & Total & $\mathbf{3 8 2}$ & $\mathbf{1 0 0}$ \\
\hline
\end{tabular}

Source: Field survey, 2018.

Table 7 shows that $13.3 \%$ of the respondents are of the opinion that, power supply in Gwagwalada are highly rationed to meet consumer demand in the study area. $21.7 \%$ of the respondents were of the view that there is hardly power supply, as the duration of stay is very short before cut out. $26.8 \%$ of the respondents in Gwagwalada opined that there is no power supply in their locality.

\subsection{Average Number of Persons per Room}

This subsection analyses the average number of persons per room.

Table 8: Average Number of Persons per Room in Gwagwalada

\begin{tabular}{|l|l|l|l|}
\hline S/N & Average number of persons per room & Frequency & Percentage (\%) \\
\hline 1 & $1-3$ & 68 & 17.8 \\
\hline 2 & $4-5$ & 127 & 33.2 \\
\hline 3 & $6-10$ & 182 & 47.6 \\
\hline 4 & 11 -above & 5 & 1.4 \\
\hline & Total & $\mathbf{3 8 2}$ & $\mathbf{1 0 0}$ \\
\hline
\end{tabular}

Source: Field survey, 2018.

Table 8 above shows that $17.8 \%$ of the respondents are of the opinion that $1-3$ persons occupy a room in 
Gwagwalada, $33.2 \%$ of the respondents attest to $4-5$ persons occupying a room averagely in Gwagwalada. $47.6 \%$ opined to 6-10 persons living in a room in Gwagwalada while about 1.4\% attest to an average of 11 persons and above living in a room in Gwagwalada. The analysis shows that the average number of persons living in a room in Gwagwalada is averagely 6-10 persons.

According to Clark (2009), adequate housing is defined as protection from cold, damp, heat, rain, wind, structural hazards, disease vector and other treat to health. This ascertain the main reason why it is improper for about 6-10 persons to occupy a single room in the study area as revealed in table 4.13, this high percentage of house occupation will account to various health treat such as heat, comfort and structural hazards due to pressure on building structure by the occupants.

\subsection{Essential Amenities in Gwagwalada}

This subsection analyses the essential amenities in Gwagwalada.

Table 9: Essential Amenities in the Study area

\begin{tabular}{|l|l|l|l|}
\hline S/N & Essential Amenities & Frequency & Percentage (\%) \\
\hline 1 & Good water supply & 25 & 6.5 \\
\hline 2 & Electricity & 16 & 4.2 \\
\hline 3 & Proper waste disposal system & 10 & 2.6 \\
\hline 4 & Proper ventilation & 11 & 2.9 \\
\hline 5 & Accessible road network & 20 & 5.2 \\
\hline 6 & All of the above & 300 & 78.6 \\
\hline & Total & $\mathbf{3 8 2}$ & $\mathbf{1 0 0}$ \\
\hline
\end{tabular}

Source: Field survey, 2018.

Table 9 above shows that $6.5 \%$ of the respondents are of the opinion that there is good water supply in Gwagwalada, $4.2 \%$ of the respondents attest to presence of electricity in Gwagwalada. 2.6\% attest to proper waste disposal system alone in the study area. $2.9 \%$ of the respondents agree to proper ventilation alone, $5.2 \%$ opined to accessible road network alone while $789.6 \%$ attest that all the essential amenities mentioned above are predominant in Gwagwalada.

\subsection{Causes of Poor Housing Conditions in Gwagwalada}

This section analyses the causes of poor housing conditions in Gwagwalada.

Table 10: Causes of Poor Housing condition in Gwagwalada

\begin{tabular}{|c|l|c|c|c|c|}
\hline S/N & \multicolumn{1}{|c|}{ Causes of poor housing conditions in Gwagwalada } & $\begin{array}{c}\text { SA } \\
(\%)\end{array}$ & $\begin{array}{c}\text { A } \\
(\mathbf{\%})\end{array}$ & $\begin{array}{c}\text { D } \\
(\mathbf{\%})\end{array}$ & $\begin{array}{c}\text { SD } \\
(\mathbf{\%})\end{array}$ \\
\hline 1. & Population explosion in Gwagwalada & 68.2 & 30.6 & 1.2 & 0 \\
\hline 2 & Lack of proper waste management in the study area & 70.6 & 29.4 & 0 & 0 \\
\hline 3 & $\begin{array}{l}\text { Poor road network hinders effective house planning implementation } \\
\text { Uneven spacing of buildings creates un-conducive environment in } \\
\text { Gwagwalada }\end{array}$ & 79.9 & 20.1 & 0 & 0 \\
\hline 5 & $\begin{array}{l}\text { Congestion and overcrowding degrades housing quality in } \\
\text { Gwagwalada }\end{array}$ & 80.2 & 19.8 & 0 & 0 \\
\hline 6 & $\begin{array}{l}\text { Lack of good water supply affects the housing quality of } \\
\text { Gwagwalada }\end{array}$ & 60.4 & 36.2 & 2.2 & 1.2 \\
\hline 7 & \begin{tabular}{l} 
Poor quality of building materials affects the housing condition \\
\hline
\end{tabular}
\end{tabular}

Source: Field survey, 2018.

Where SA = Strongly Agreed, D = Disagreed, A = Agreed, SD = Strongly Disagree

Table 10 shows that $98.8 \%$ of the respondents are of the opinion and view that pressure arising from increase in population in Gwagwalada results to poor housing condition in the area. $100 \%$ of the respondents attest that lack of proper waste management mechanism creates un-conducive environment degrading housing quality in Gwagwalada. 98.4\% of the respondents attest that poor road network hinders effective house planning implementation in Gwagwalada. 100\% of the respondents attest that uneven spacing of buildings creates unconducive environment in Gwagwalada. 100\% i.e. all the respondents attest that congestion and overcrowding degrades housing quality in Gwagwalada. $96.6 \%$ of the respondents are of the view that lack of good water supply affects the housing quality of Gwagwalada. 100\% of the respondents attest that the use of inferior materials with low standard such as roofing materials, sand, cements, and concrete among others affects the housing condition.

\subsection{Effects of Poor Housing}

This section analyses the effects of poor housing condition in Gwagwalada. 
Table 11: Effects of Poor Housing Condition in Gwagwalada.

\begin{tabular}{|l|l|l|l|l|l|}
\hline S/N & Effects of Poor Housing Condition in Gwagwalada & SA & A & D & SD \\
\hline 1 & Poor housing condition results to un-conducive environment. & 81.4 & 17.6 & 1.0 & 0 \\
\hline 2 & $\begin{array}{l}\text { Poor housing creates a platform in which diseases are easily breed and } \\
\text { transferred }\end{array}$ & 90.2 & 6.7 & 2.1 & 1.0 \\
\hline 3 & Poor waste management sites turn breeding ground for pathogens & 91.6 & 8.4 & 0 & 0 \\
\hline 4 & Communicable diseases spreads within congested and overcrowded rooms & 78.0 & 20.9 & 1.1 & 0 \\
\hline 5 & Poor housing conditions degrades ones standard of living & 88.8 & 7.7 & 2.3 & 1.2 \\
\hline 6 & Poor housing condition affects the inhabitants personal hygiene & 93.4 & 3.6 & 2.0 & 1.0 \\
\hline 7 & Constant repairs and replacement of structures and dilapidated parts & 64.2 & 35.8 & 0 & 0 \\
\hline 8 & $\begin{array}{l}\text { Poor housing condition affects the inhabitants taste and fashion as well as } \\
\text { their perception towards quality housing }\end{array}$ & 86.5 & 8.0 & 3.4 & 2.1 \\
\hline
\end{tabular}

Source: Field survey, 2018.

Table 11 analysis shows that $99 \%$ of the respondent opined that poor housing condition results to unconducive environment. $96.9 \%$ of the respondents agree that poor housing condition creates a platform in which diseases are easily breed and transferred. $100 \%$ of the respondents i.e. the entire respondents attest that poor waste management sites can turn breeding grounds for pathogens (disease causing organism). 98.9\% of respondents are of the opinion that overcrowded and congested rooms easily give room for the spreading of communicable diseases among humans. $96.5 \%$ of the respondents attest that poor housing conditions degrades ones standard of living. $97.0 \%$ of the respondents agreed that poor housing condition affects the inhabitant's personal hygiene in Gwagwalada. 100\% of the respondents i.e. the entire respondents opined that constant repairs and replacement of structures and dilapidated parts in Gwagwalada. 94.5\% of the respondents attest that poor housing condition affects the inhabitants taste and fashion as well as their perception towards quality housing in Gwagwalada.

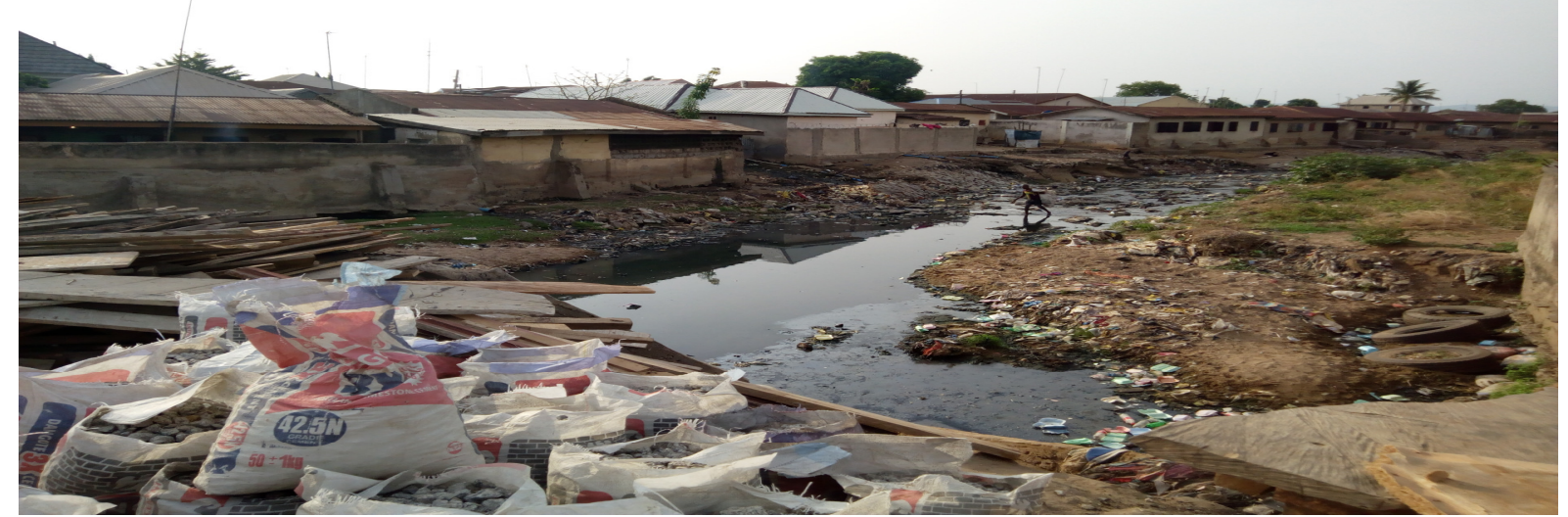

Plate 1: Un-conducive state of housing in Kutunku, Gwagawalada satellite town, Abuja-Nigeria.

Source: Author's field survey, 2018

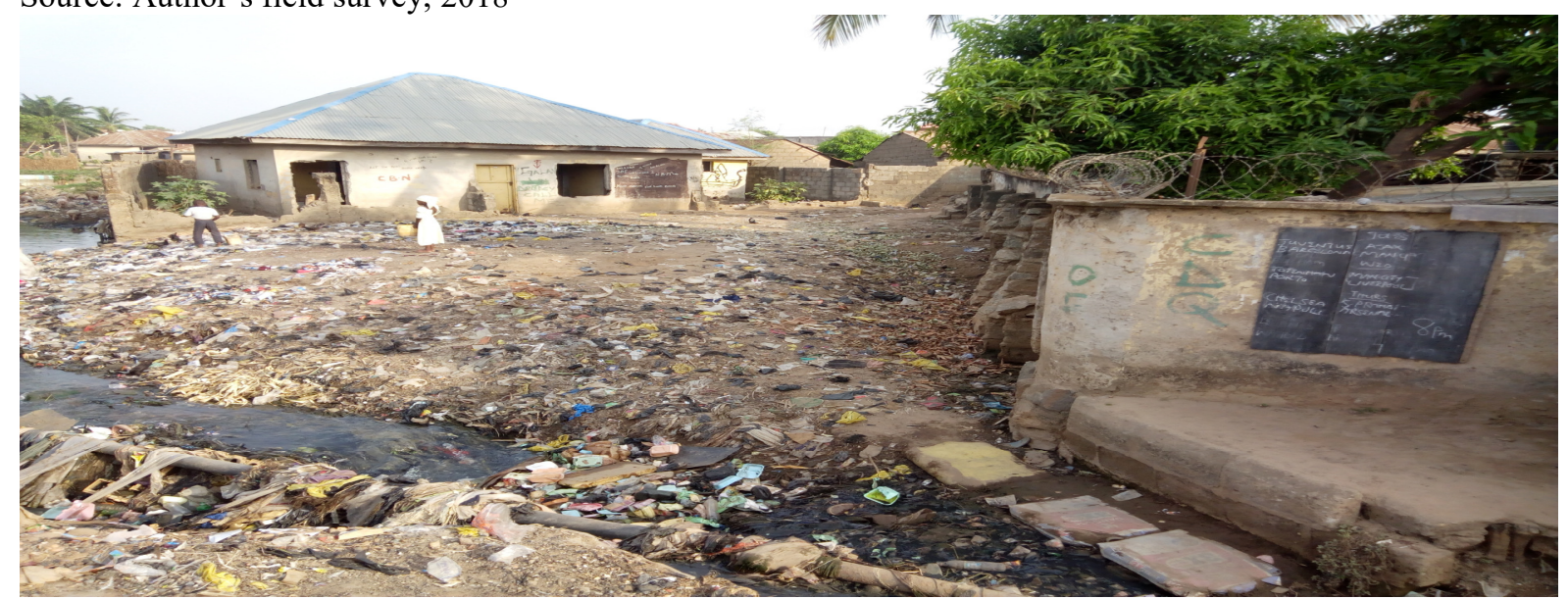

Plate 2: Poor state of housing in Angwan-Dodo, Gwagawalada satellite town, Abuja-Nigeria

Source: Author's field survey, 2018

Plate 1 and 2 above shows clearly the poor states of housing condition in parts of Gwagwalada satellite 
town. These locations faced with dilapidating structures host majority of the population of the study area. The inhabitants are exposed to diseases and pathogens, hence are prone to poor state of health due to poor hygiene, lack of proper waste management system, clustered buildings, poor drainage channels, lack of quality domestic water supply, and un-conducive environment.

\subsection{Statistical Testing/Hypothesis verification}

$\mathbf{H}_{\mathbf{0}}$ : there is no significant difference among the problems associated with poor housing conditions in Gwagwalada

\begin{tabular}{|l|c|c|}
\hline S/N & Problems Associated with Poor Housing Condition & Total Percentage Agree \\
\hline I & Un-conducive environment $\quad$ (A) & 99.0 \\
\hline Ii & Easy spread of diseases (B) & 96.9 \\
\hline Iii & Breeding ground for pathogens (C) & 100.0 \\
\hline Iv & Communicable diseases (D) & 98.9 \\
\hline V & Degraded standard of living (E) & 96.5 \\
\hline Vi & Degraded personal hygiene (F) & 97.0 \\
\hline Vii & Dilapidated housing standard (G) & 100.0 \\
\hline Viii & Degraded housing standard (H) & 94.5 \\
\hline
\end{tabular}

\begin{tabular}{|c|c|c|c|c|c|}
\hline \multicolumn{6}{|c|}{ Source: Field survey, 2018} \\
\hline & $\mathbf{0}$ & $\mathbf{E}$ & 0-E & $(0-E)^{2}$ & $\frac{(0-E)^{2}}{F}$ \\
\hline $\mathrm{A}$ & 99.0 & 97.85 & 1.15 & 1.323 & 0.014 \\
\hline $\mathrm{B}$ & 96.9 & 97.85 & -0.95 & 0.903 & 0.009 \\
\hline $\mathrm{C}$ & 100.0 & 97.85 & 2.15 & 4.623 & 0.047 \\
\hline $\mathrm{D}$ & 98.9 & 97.85 & 1.05 & 1.103 & 0.011 \\
\hline $\mathrm{E}$ & 96.5 & 97.85 & -1.35 & 1.823 & 0.019 \\
\hline $\mathrm{F}$ & 97.0 & 97.85 & -0.85 & 0.723 & 0.007 \\
\hline $\mathrm{G}$ & 100.0 & 97.85 & 2.15 & 4.623 & 0.047 \\
\hline $\mathrm{H}$ & 94.5 & 97.85 & -3.35 & 11.223 & 0.115 \\
\hline
\end{tabular}

Calculated value $\left(\mathrm{X}^{2}\right)=0.269, \mathrm{~N}=8$, Degree of freedom $(\mathrm{D} . \mathrm{f})=8-1=7$.

At $95 \%$ level of significance, critical value of $X^{2}$ at 7 degree of freedom is 14.067 . This value is larger than the calculated value of $\mathrm{X}^{2}$ at 0.269 . Hence, the null hypothesis $\left(\mathrm{H}_{\mathrm{o}}\right)$ is accepted. Thus there is no significant difference among the effects of poor housing condition in Gwagwalada area council. The analysis revealed that $99.0 \%$ of the respondents account for un-conducive environment, which revealed the reasons for spread of diseases, breeding ground for pathogens as well as spread of communicable diseases in the study area. These problems account for degraded living standard, low personal hygiene and consequently affect housing standard and dilapidation of building structures in the study area. The inter-dependency effect of poor housing condition in the study area revealed that there is no significant difference among the effect of poor housing conditions as earlier listed.

\section{SUMMARY AND CONCLUSION}

This study has shown that within Gwagwalada there exist poor housing conditions. The consistent dilapidation of structures and building parts is largely due to the presence exerted on houses by the ever growing population in Gwagwalada. Building is one aspect of human culture that has been neglected over decades. The standard and principles of building have not been followed duly by the people only but a few individuals. People living within Gwagwalada built their houses in various pattern and shape neglecting the recommendations of town planners. This often leads to constant review of the Gwagwalada master plan.

The research found that the causes of poor housing conditions in Gwagwalada; Population explosion in Gwagwalada, Lack of proper waste management in Gwagwalada, Poor road network which hinders effective house planning implementation, Uneven spacing of buildings which creates un-conducive environment, Congestion and overcrowding with degrading effect on housing standard, Lack of good water supply in the area, and poor quality of building materials among other causes were mentioned. The research investigated the effects of poor housing conditions in Gwagwalada, among these effects mentioned were: un-conducive environment, easy spread of diseases, degraded housing standard, constant repairs, congestion and overcrowding resulting to spread of communicable diseases. 


\section{RECOMMENDATIONS}

The following recommendations were advised:

i. There should be strict implementation of laws governing building, its standard and requirements.

ii. Government should spell out sanctions on defaulters and fines where applicable to manage and control building sub-standard houses in the area.

iii. Appropriate measures should be taken by the relevant planning authority such as the Federal Capital Development Authority (FCDA) to provide access road, drainage, waste disposal system and aesthetics in order to improve the deplorable state of the environment in Gwagwalada.

iv. Government should provide the necessary neighborhood facilities within the reach of the individual dwelling units in the study area.

v. Federal Mortgage Bank of Nigeria (FMBN) should be empowered and made approachable by the people so they can obtain adequate loan to build standard houses in Gwagwalada.

vi. Government should gather data on houses and infrastructures within Gwagwalada to plan for future upgrades or new housing.

vii. Illegal structures should be demolished and laws should be enacted for approved layouts and plans to be followed. This would bring about cleaner and more conducive environment in Gwagwalada.

viii. Government has the highest duty in terms of finding solution to housing problems and needs. Due to the organic nature of Gwagwalada, it is imperative for government to understand urban renewal and redevelopment programs.

ix. Government should invest in housing, considering it as a must a do or die agenda yearly to have a better environment

x. Proper waste disposal systems should made available in Gwagwalada. This waste can be collected daily or weekly from homes and taken to their disposal sites.

xi. Houses should be built with proper ventilation channels, good drainage systems, toilets and bathrooms, kitchens among others with space about buildings for recreation and parking in Gwagwalada.

xii. People should be allowed to participate in decision making which directly affects their living conditions. Community development is a form of grassroots democracy and therefore should be put in place for adequate housing in Gwagwalada.

\section{ACKNOWLEDGEMENT}

The authors wish to acknowledge the National Population Commission for providing the secondary data used in this study.

\section{REFERENCES}

Adedeji L.P (2012), "Housing in Nigerian National Development” NITP journal, vol.iv and v.

Adeniyi G. (2014), Urbanization and Urban Decay in Nigeria, In: P Onibokun, F Olokesusi and L Egunjobi (eds) Urban Renewal in Nigeria, NISER, Ibadan.

Agbola T. (2015), Sustainable Approach to Slum Prevention in Nigeria: Opportunities, Challenges and Strategies, Key Note Paper Presented at the Second House of Representatives' Committee on Habitat on Sustainable Slum Upgrading in Urban Areas and Held at the ShehuYar'adua Center, Abuja, 25-27 October.

Aluko, H. (2016), Saving African Metropolises: Case Study of Accra: - Growing By Chance or By Design? Cdrom: Proceeding of the Africa Union of Architects XXXIst Council Meeting and West African Regional Congress, GIMPA, Accra, Ghana.

Amole E. (2012), Spatial pattern of housing modernization in the traditional residential areas of Ilorin, The Nigerian Geographical Journal, 23: 147-161.

Balogun .A. (2001), "The position and influence of the Gwagwalada Area Council" University of Lagos press, pp.35-42

Egunjobi L. (2012), Urban renewal: Issues, policies, strategies and planning, pp. 33- 43, in Urban Renewal in Nigeria.P. G. Onibokun, F. Olokesusi and LayiEgunjobi (Eds.), NISER, Ibadan.

Ejaro S.P (2013). "Land accessibility problem in Nigeria: A case study of Gwagwalada, Research journal of social science and management, volume II, page 160-162.

Major G. (2013) "Contemporary geography and housing pattern of the Nigerian setting” Best sellers publisher, Vol. 2, page 356-272.

Jackson V. (2010), "The Urban Poor Perception of Housing Conditions" in Taylor, R. or (ed) urban development in Nigeria planning, Housing and Land policy, Chapter 12. Pp 130-144. Anerburg, New Jersey.

Lucas H. (2011), The State of Repair of Buildings in Akure, Nigeria, Proceedings of CIB W107 Construction in Developing Economies International Symposium, "Construction in Developing Economies: New Issues and Challenges", 18-20 January, Santiago, Chile, paper 3.1 CD ROM.

Clark (2009), "Towards the formulation of appropriate Housing Standards in Nigeria" Journal of Tropical 
Architecture, June 2010, Pp 148-156

National population commission (2009), population growth report, the adverse effects on the structural employment, NPC journals V (28), page (18).

Nwotana J. (2013), Urbanization in a Development Context: Patterns,Problems and Prospects in Nigeria, Annual conference of the Nigerian Economic Society, pp.11-37.

Onibokun A.G. (2012), Public Utilities and Social Services in Nigerian urban Centres: Problemsand Guides for Africa, IDRC, Canada and NISER, Ibadan, Oyo State, Nigeria.

Onibokun P. (2002), "Urban Housing in Nigeria" NISER pp 89, 101-361.

UNHSP (2006), the State of AFRICA Cities: A Framework for Addressing Urban Challenges in Africa (UNHABITAT); Michael Jones Software, Nairobi Kenya. United Nations Centre for Human Settlements (UNCHS), an Urbanizing World: Global Report on Human Settlements, Oxford University Press.

Yunusa A. (2013), Planning Implications of Housing Redevelopment in Density Areas of Ogbomoso, Nigeria: a pilot study". Journal of Human Ecology, Kamla-Raj Enterprises, Delhi, India, Vol. 20, No. 3, pp273- 277.

Yusuf A. (2012), Built Environment Decay and HealthSituation of Slum Dwellers in Residential Cores of Akure, Nigeria, American Journal of Human Ecology Vol. 1, No. 2, 2012, 33-39, ISSN 2167-9622 Print/ ISSN 2167-9630 Online (C) 2012 World Scholars. 